\title{
Side effects of yttrium-90 radioembolization
}

\author{
Ahsun Riaz *, Rafia Awais and Riad Salem \\ Section of Interventional Radiology, Department of Radiology, Robert H. Lurie Comprehensive Cancer Center, Northwestern University, Chicago, IL, USA
}

\section{Edited by:}

Kathy Willowson, University of

Sydney, Australia

Reviewed by:

Luigi Aloj, Istituto Nazionale Tumori IRCCS "Fondazione G. Pascale", Italy

Bruno Sangro, Clinica Universidad de Navarra, Spain

\section{*Correspondence:}

Ahsun Riaz, Section of Interventional

Oncology, Department of Radiology,

676 N. St. Clair, Suite 800, Chicago, IL

60611, USA

e-mail:ahsun-riaz@

fsm.northwestern.edu
Limited therapeutic options are available for hepatic malignancies. Image guided targeted therapies have established their role in management of primary and secondary hepatic malignancies. Radioembolization with yttrium-90 (90) microspheres is safe and efficacious for treatment of hepatic malignancies. The tumoricidal effect of radioembolization is predominantly due to radioactivity and not ischemia. This article will present a comprehensive review of the side effects that have been associated with radioembolization using $90 Y$ microspheres. Some of the described side effects are associated with all transarterial procedures. Side effects specific to radioembolization will also be discussed in detail. Methods to decrease the incidence of these potential side effects will also be discussed.

Keywords: radioembolization, complications of cancer therapy, side effects, liver neoplasms, radiation effects

\section{INTRODUCTION}

\section{PRIMARY HEPATIC MALIGNANCIES}

Hepatocellular carcinoma (HCC) and intra-hepatic cholangiocarcinoma (ICC) are primary liver malignancies. HCC is much more common than $\operatorname{ICC}(1,2)$. Surgical resection is reserved for a select group of patients with resectable disease (3). Orthotopic liver transplantation may be performed in patients with HCC who are within the Milan criteria (4). Chemoembolization and radiofrequency ablation are considered standard locoregional therapies for patients with unresectable HCC $(5,6)$. Radioembolization is an alternative locoregional therapy, which has established its role in the management of primary liver tumors.

\section{SECONDARY HEPATIC MALIGNANCIES}

Malignancies commonly metastasize to the liver (7). Hepatic metastases are generally managed by surgical resection or systemic medical treatments. Radioembolization for hepatic metastases is safe and effective in secondary hepatic malignancies (8-10).

\section{RADIOEMBOLIC AGENTS}

${ }^{90} \mathrm{Y}$ microspheres are used in treatment of hepatic malignancies. The details of ${ }^{90} \mathrm{Y}$ are beyond the scope of this manuscript. Table 1 presents the relevant differences in the two available ${ }^{90} \mathrm{Y}$ microsphere devices.

SIR-Spheres ${ }^{\circledR}$ are FDA-PMA (Food and Drug AdministrationPremarket Approval) approved for metastatic colorectal cancer to the liver (11). TheraSpheres ${ }^{\circledR}$ are FDA approved under HDE (humanitarian device exemption) for radiation treatment or as neo-adjuvant to surgery or transplantation in patients with HCC who can have appropriately placed hepatic arterial catheters (12). This device is indicated for HCC patients with partial or branch portal vein thrombosis/occlusion when clinical evaluation warrants the treatment. Other investigational uses of these devices are being employed.

Multiple other radioactive devices are being investigated for transarterial therapy. These include iodine-131 labeled iodized oil, rhenium-188 HDD labeled iodized oil, phosphorus-32 glass microspheres, and Milican/holmium-166 microspheres.

\section{PRE-TREATMENT ASSESSMENT}

Pre-treatment evaluation of radioembolization includes:

- Pre-treatment clinical evaluation

- Pre-treatment laboratory evaluation

- Pre-treatment radiological evaluation

- Pre-treatment angiography

\section{Pre-treatment clinical evaluation}

A multidisciplinary team consisting of hepatologists, med$\mathrm{ical} /$ surgical/radiation oncologists, transplant surgeons, and interventional radiologists should select patients for radioembolization. A clinic visit is necessary. A history, which includes patient's prior surgical and medical therapies, is necessary. A recent article suggested safety of radioembolization in patients who have had prior partial hepatectomies (13). The patient's performance status per Eastern Cooperative Oncology Group (ECOG) should be assessed.

\section{Pre-treatment laboratory evaluation}

Appropriate laboratory tests including but not limited to liver function tests and corresponding tumor markers should be performed to ascertain baseline values. For patients with cirrhosis, it is essential to classify patients. The Child-Pugh classification is commonly employed by multiple disciplines and includes the following variables:
a) Serum bilirubin
b) Serum albumin
c) $\mathrm{PT} / \mathrm{INR}$
d) Encephalopathy
e) Ascites 
Table 1 | Yttrium-90 microsphere devices.

\begin{tabular}{|c|c|c|}
\hline Name & TheraSphere ${ }^{\circledR}$ & SIR-Spheres ${ }^{\circledR}$ \\
\hline Material & Glass microsphere & Resin microsphere \\
\hline $\begin{array}{l}\text { Size of particle } \\
\text { (microns) }\end{array}$ & $20-30$ & $20-60$ \\
\hline Embolic effect & Mild & Mild to moderate \\
\hline Doses & $3-20 \mathrm{GBq}$ & $3 \mathrm{GBq}$ \\
\hline $\begin{array}{l}\text { Number of particles per } \\
\text { treatment }\end{array}$ & 1.2-8 million & Up to 30 million \\
\hline
\end{tabular}

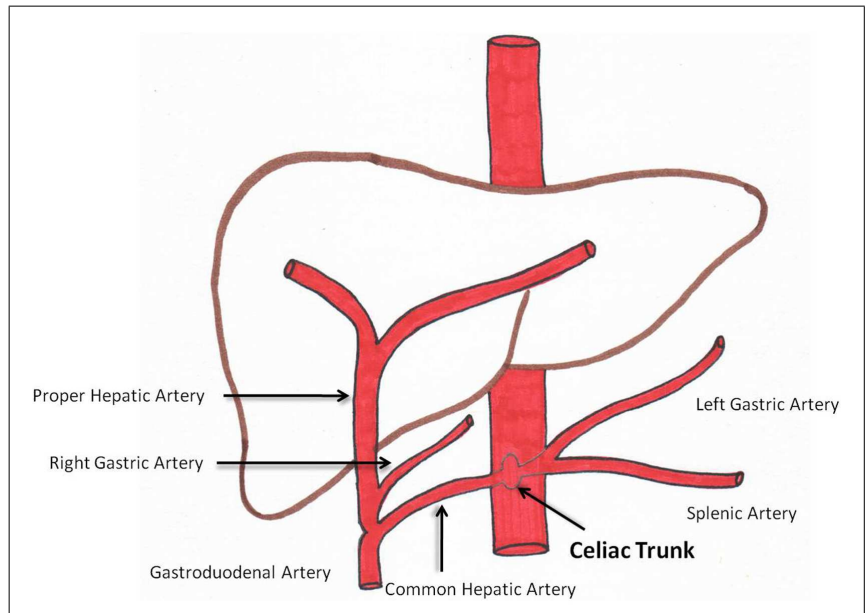

FIGURE 1 | Schematic representation of celiac arterial anatomy.

\section{Pre-treatment cross-sectional imaging evaluation}

A triphasic liver CT or MRI is usually performed to evaluate the following:

a) Extent of disease

b) Location of disease

c) Relative tumor hypervascularity

d) Variant vascular anatomy

\section{Pre-treatment angiography}

Angiography prior to radioembolization is essential. This provides the interventional radiologist with knowledge of the hepatic arterial anatomy and aberrant vasculature (14). Figure $\mathbf{1}$ is a diagram representing conventional celiac arterial anatomy.

An aortogram assesses aortic atherosclerosis and tortuosity. A superior mesenteric angiogram is essential to determine variant vessels to the liver. Delayed images can assess the patency of the portal vein. A celiac angiogram determines hepatic vasculature and variants. Segment 1 tumors require special attention given various potential contributing feeders (15). More selective angiography with microcatheters/microwires is recommended to determine a safe and efficacious point of radioembolization to the tumor.

\section{Coil embolization}

Coil embolization of communicating vessels that may lead to aberrant microsphere deposition can be performed if necessary. The aberrant deposition of microspheres in the gastrointestinal tract
(GIT) or pancreas can have grave consequences (16-18). Some vessels that may need to be coil embolized prior to treatment are: gastroduodenal artery (GDA), right gastric artery (RGA), accessory left gastric artery, falciform artery, phrenic arteries, inferior esophageal artery, supraduodenal artery, and retroduodenal artery.

Pre-treatment prophylactic coil embolization is dependent on the following variables $(19,20)$ :

- Experience of the treating physician

- Planned location of radio-microsphere delivery

- Size of vessel

Collateral hepaticoenteric flow can develop following coil embolization. This may increase aberrant microsphere deposition on following repeat treatments. Theoretically, if the interval between coil embolization and radioembolization is long, this phenomenon can also occur during the initial treatment. Further research on this issue is needed.

\section{POTENTIAL METHODS TO ENHANCE/CONFIRM TUMOR DELIVERY OF RADIOMICROSPHERES \\ C-arm CT}

Appropriate tumor targeting is now routinely confirmed by using C-arm CT. This method aids in accurately recognizing non-tumor/non-hepatic contrast delivery.

\section{Consolidation of hepatic arterial flow}

Variant hepatic artery and parasitized hepatic artery can be coil embolized prior to radioembolization. This leads to intra-hepatic collateralization in preparation for radioembolization.

\section{Angiotensin II}

A systematic review concluded that Angiotensin II could increase tumor to non-tumor blood flow by approximately up to threefold (21). However, further studies are needed to determine systemic safety profile as Angiotensin II could increase systemic blood pressure.

\section{Degradable starch microspheres}

A five patient analysis on the use of degradable starch microspheres as an embolizate to normal hepatic parenchyma during radioembolization was performed. Post-radioembolization SPECT/CT demonstrated sparing of normal parenchyma (22). This is an interesting concept, which needs validation.

\section{TECHNETIUM-99M MACROAGGREGATED ALBUMIN (99M TC-MAA) SCAN} A ${ }^{99 m}$ Tc-MAA scan is performed to assess the lung shunt fraction (LSF) and splanchnic shunting. Figure 2 shows a hypervascular HCC. Figure 3 shows planar scintigraphic imaging from a nuclear medicine scan demonstrating significant LSF. SPECT can enhance detection of splanchnic flow. However, conventional angiography is considered standard for identifying GI uptake by most interventional radiologists (23).

In 2011, Sabet et al. published an article demonstrating that oral administration of sodium perchlorate before the test angiogram with ${ }^{99 \mathrm{~m}} \mathrm{Tc}$-MAA resulted in effective avoidance of free ${ }^{99 \mathrm{~m}} \mathrm{Tc}$ pertechnetate concentration and decreased incidence of equivocal findings in the gastroduodenal region (24). 


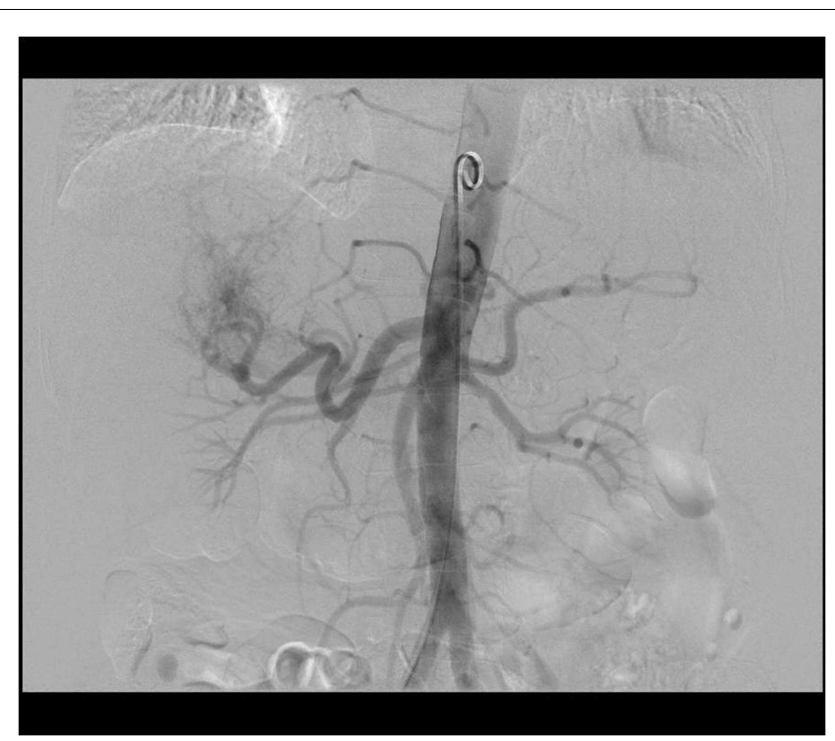

FIGURE 2 | Angiographic image demonstrating hypervascular tumor.

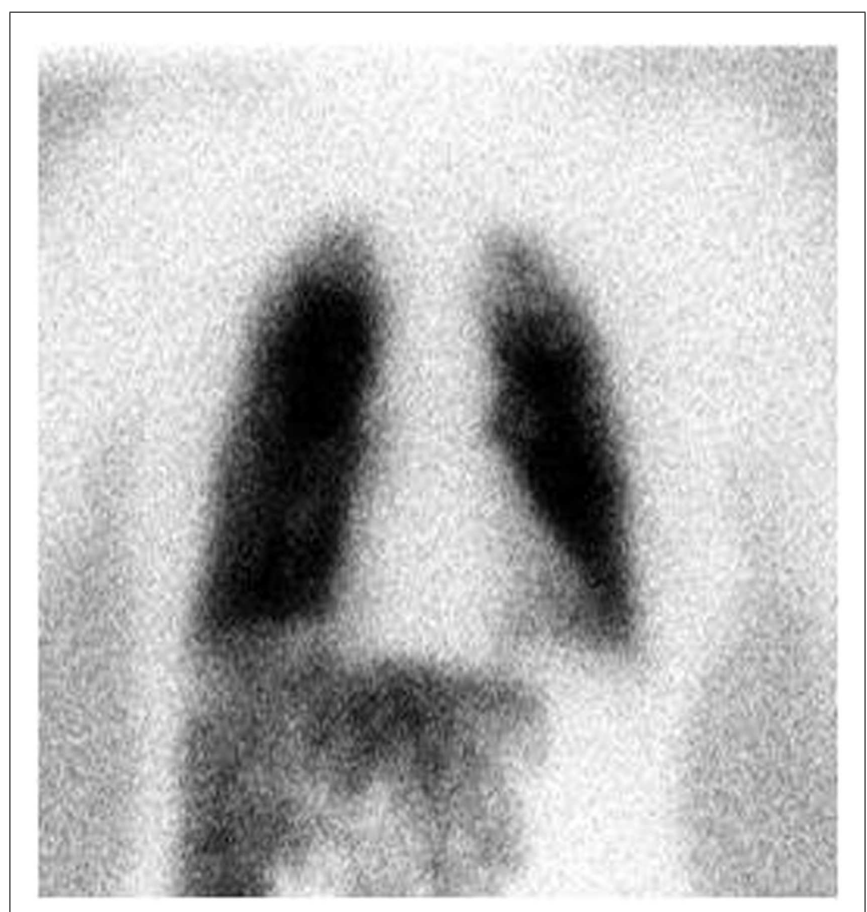

FIGURE 3 | Planar Tc-99m MAA scan demonstrating high LSF (76\%).

\section{DOSE CALCULATIONS}

A brief overview of dose calculations is important to understand potential complications. Recent data suggest that ${ }^{99 m}$ Tc-MAA (simulates ${ }^{90} \mathrm{Y}$ ) and ${ }^{99} \mathrm{~m} \mathrm{Tc}$-sulfur colloid (SC) (accumulates in reticuloendothelial tissue), dual tracer SPECT/CT may provide more accurate dose calculations as this method provides a more accurate dose to functional liver (DFL) (25). Research is being done on the utilization of PET/CT for dosimetry (26).

\section{Dose calculation for TheraSphere $B^{\circ}$}

Dose is calculated for TheraSphere ${ }^{\circledR}$ using the following formula:

$$
\text { Dose }(\mathrm{Gy})=\frac{50[\text { Injected activity }(\mathrm{GBq})][1-\mathrm{LSF}]}{\text { Liver Mass }(\mathrm{kg})}
$$

Per the TheraSphere ${ }^{\circledR}$ package insert, the upper limit of injected activity to the lungs is $0.61 \mathrm{GBq}(12)$.

\section{Dose calculation for SIR-Sphere ${ }^{\circledR}$}

The two acceptable methods for individual patient dose calculation for SIR-Sphere ${ }^{\circledR}$ include the partition model and empirical model (11). The empirical model is based on dose known from previously published clinical data and chooses the safest and most effective dose from it. The recommended patient dose is based on percent involvement by the tumor in the liver. A $3 \mathrm{GBq}$ vial is used for greater than $50 \%$ hepatic tumor involvement; a $2.5 \mathrm{GBq}$ vial is used for 25 to $50 \%$ hepatic tumor involvement; a $2 \mathrm{GBq}$ vial is used for less than $25 \%$ hepatic tumor involvement. The package insert for SIR-sphere ${ }^{\circledR}$ acknowledges that individual patient dose calculation is complex.

Additionally, LSF affects dose reduction. If there is less $10 \%$ LSF, there is no reduction in dose. If there is $10-15 \%$ LSF, the dose is reduced by a factor of $20 \%$. If there is $15-20 \%$ LSF, the dose is reduced by a factor of $40 \%$. If the LSF is greater than $20 \%$, treatment is not recommended.

\section{SINGLE-SESSION RADIOEMBOLIZATION}

A recently published method of single-session radioembolization (pre-treatment angiography/Tc-99m MAA scan/radioembolization on same day) employed by the group showed no reportable events. In this analysis, planar scintigraphy was performed in $2 \mathrm{~h}$ following administration of Tc-99m MAA and LSF was determined. Final dosimetry calculations were performed while the patient was being transferred back from nuclear medicine to interventional radiology. This method decreased the costs and time between initial clinical assessment and radioembolization (27). It should be noted that this method requires high level of expertise and efficient communication between the nuclear medicine department, physicist, and interventional radiologist.

\section{POST-TREATMENT ASSESSMENT Post-treatment imaging}

At our institution, cross-sectional contrast enhanced imaging (triphasic CT or MRI) is obtained at 1 month following treatment and at 3 month intervals following the first post-treatment imaging. This protocol evaluates response, or lack thereof, to treatment.

Bremsstrahlung SPECT/CT and PET/CT are being investigated for evaluating post-treatment technical success and predicting treatment efficacy (26). Time of flight PET/CT has improved spatial resolution when compared to Bremsstrahlung SPECT/CT. Aberrant microsphere deposition may also be identified using SPECT/CT and/or PET/CT. Gupta et al. have published a case report of aberrant delivery of ${ }^{90} \mathrm{Y}$ to the duodenum identified on PET/CT performed after radioembolization (28). Early 
knowledge of aberrant microsphere deposition may lead to early interventions.

\section{Post-treatment laboratory evaluation}

Post-treatment LFTs and complete blood count are usually performed 1 month following treatment. Tumor markers (such as alpha-fetoprotein for HCC) may aid in assessing response to therapy.

\section{COMPLICATIONS OF RADIOEMBOLIZATION}

The complications occurring after radioembolization (29) are discussed in detail below. Table 2 summarizes available data on post-radioembolization complications.

Please note that it is important to standardize recording and reporting toxicities. Clinical and laboratory toxicities may be classified according to the standard criteria such as the Common Terminology Criteria for Adverse Events (CTCAE) version 4.0, whenever possible (43). Tables 3 and $\mathbf{4}$ give some of the relevant clinical and laboratory (investigational) toxicities according to CTCAE v4.0.

\section{POST-RADIOEMBOLIZATION SYNDROME}

A post-radioembolization syndrome (PRS) includes fatigue, nausea/vomiting, abdominal pain/discomfort, and/or cachexia. PRS is less severe than that observed after embolic therapies. Hospitalization is rarely required (44-47). Incidence of PRS ranges from 20 to $70 \%(17,44-46)$. In a two-institution, 112-patient analysis, the incidence of PRS was 70\% (48). Patients should be made aware of these potential side effects before therapy. A 2-week postradioembolization telephone call is recommended to inquire for symptoms of PRS. A clinic visit 1 month following treatment is recommended to clinically assess the patient.

\section{NAUSEA/VOMITING}

Nausea and vomiting may occur following radioembolization. Based on this experience, antinauseants/antiemetics such as

Table 2 | Summary of available data on post-radioembolization complications.

\begin{tabular}{|c|c|c|c|}
\hline Complications & Reference & Materials & Findings/conclusion(s) \\
\hline \multirow[t]{4}{*}{ Hepatic } & Young et al. (30) & $41 \mathrm{HCC}$ patients with multiple treatments & Okuda I: can tolerate up to $390 \mathrm{~Gy}$ \\
\hline & & to same segment/lobe & Okuda II: can tolerate up to $196 \mathrm{~Gy}$ \\
\hline & Sangro et al. (31) & 45 Patients with liver tumors & $\begin{array}{l}\text { RILD increases with: increasing age, whole liver treatment, } \\
\text { and elevated baseline bilirubin levels }\end{array}$ \\
\hline & Kennedy et al. (32) & $\begin{array}{l}680 \text { Liver tumor }{ }^{90} \mathrm{Y} \text { treatments with resin } \\
\text { microspheres }\end{array}$ & $\begin{array}{l}\text { RILD increases with: increased activity and use of the } \\
\text { empiric method for dose calculation }\end{array}$ \\
\hline \multirow[t]{8}{*}{ Biliary } & Atassi et al. (33) & 327 Patients with liver tumors & Biliary necrosis $(n=17)$ \\
\hline & & & Bilomas $(n=3)$ \\
\hline & & & Cholecystitis $(n=2)$ \\
\hline & & & Gall bladder wall rent $(n=3)$ \\
\hline & & & Abscess $(n=1)$ \\
\hline & & & Biliary strictures $(n=8)$ \\
\hline & $\mathrm{Ng}$ et al. (34) & 2 Biliary complications & Biliary stricture $(n=1)$ \\
\hline & & & Cholangitis $(n=1)$ \\
\hline \multirow[t]{5}{*}{ Pulmonary } & Leung et al. (35) & 80 Patients with liver tumors & Radiation pneumonitis ( $n=5 ; 6.3 \%)$ \\
\hline & & & Pulmonary complications increase in patients with \\
\hline & & & LSF $>13 \%$ \\
\hline & Salem et al. (36) & 403 Patients with liver tumors & Radiation pneumonitis $(n=0)$ \\
\hline & & & Grade I toxicities per RTOG/EORTC ${ }^{a}$ criteria ( $\left.n=10 ; 19 \%\right)$ \\
\hline \multirow[t]{6}{*}{ Gastrointestinal } & Carretero et al. (37) & 78 Patients & Gastroduodenal injury (4\%) \\
\hline & Murthy et al. (38) & Patients with liver tumors & $\begin{array}{l}\text { Important to recognize hepaticoenteric arterial } \\
\text { communications }\end{array}$ \\
\hline & Mallach et al. (39) & One case of gastroduodenal ulceration & Endoscopy is required to confirm \\
\hline & Szyszko et al. (40) & 21 Patients & Gl ulceration in $29 \%$ patients \\
\hline & South et al. (41) & 27 Patients & Gl ulceration in $11 \%$ patients \\
\hline & Lam et al. (42) & 247 Patients & Gl ulceration in $3.2 \%$ \\
\hline
\end{tabular}

${ }^{a}$ RTOG/EORTC, radiation therapy oncology group/European organization for research and treatment of cancer. 
Table 3 | Some relevant clinical toxicities according to the CTCAE v4.0

\begin{tabular}{|c|c|c|c|c|c|}
\hline \multirow[t]{2}{*}{ Clinical toxicity } & \multicolumn{5}{|c|}{ Grade } \\
\hline & 1 & 2 & 3 & 4 & 5 \\
\hline Diarrhea & $\begin{array}{l}\text { Increase of < } 4 \text { stools per day } \\
\text { over baseline; mild increase } \\
\text { in ostomy output compared } \\
\text { to baseline }\end{array}$ & $\begin{array}{l}\text { Increase of four to six stools } \\
\text { per day over baseline; } \\
\text { moderate increase in ostomy } \\
\text { output compared to baseline }\end{array}$ & $\begin{array}{l}\text { Increase of } \geq 7 \text { stools per day } \\
\text { over baseline; incontinence; } \\
\text { hospitalization indicated; } \\
\text { severe increase in ostomy } \\
\text { output compared to baseline; } \\
\text { limiting self care ADL }\end{array}$ & $\begin{array}{l}\text { Life-threatening } \\
\text { consequences; urgent } \\
\text { intervention indicated }\end{array}$ & Death \\
\hline Nausea & $\begin{array}{l}\text { Loss of appetite without } \\
\text { alteration in eating habits }\end{array}$ & $\begin{array}{l}\text { Oral intake decreased } \\
\text { without significant weight } \\
\text { loss, dehydration or } \\
\text { malnutrition }\end{array}$ & $\begin{array}{l}\text { Inadequate oral caloric or } \\
\text { fluid intake; tube feeding, } \\
\text { TPN, or hospitalization } \\
\text { indicated }\end{array}$ & & \\
\hline Pancreatitis & - & $\begin{array}{l}\text { Enzyme elevation or } \\
\text { radiologic findings only }\end{array}$ & $\begin{array}{l}\text { Severe pain; vomiting; } \\
\text { medical intervention } \\
\text { indicated (e.g., analgesia, } \\
\text { nutritional support) }\end{array}$ & $\begin{array}{l}\text { Life-threatening } \\
\text { consequences; urgent } \\
\text { intervention indicated }\end{array}$ & Death \\
\hline Vomiting & $\begin{array}{l}\text { One to two episodes } \\
\text { (separated by } 5 \mathrm{~min} \text { ) in } 24 \mathrm{~h}\end{array}$ & $\begin{array}{l}\text { Three to five episodes } \\
\text { (separated by } 5 \mathrm{~min} \text { ) in } 24 \mathrm{~h}\end{array}$ & $\begin{array}{l}\geq 6 \text { episodes (separated by } \\
5 \mathrm{~min} \text { ) in } 24 \mathrm{~h} \text {; tube feeding, } \\
\text { TPN or hospitalization } \\
\text { indicated }\end{array}$ & $\begin{array}{l}\text { Life-threatening } \\
\text { consequences; urgent } \\
\text { intervention indicated }\end{array}$ & Death \\
\hline Abdominal pain & Mild pain & $\begin{array}{l}\text { Moderate pain; limiting } \\
\text { instrumental ADL }\end{array}$ & $\begin{array}{l}\text { Severe pain; limiting self care } \\
\text { ADL }\end{array}$ & - & - \\
\hline
\end{tabular}

Table 4 | Some relevant laboratory toxicities according to the CTCAE v4.0.

\begin{tabular}{|c|c|c|c|c|c|}
\hline \multirow[t]{2}{*}{ Laboratory toxicity } & \multicolumn{5}{|c|}{ Grade } \\
\hline & 1 & 2 & 3 & 4 & 5 \\
\hline Bilirubin & $\begin{array}{l}\text { ULN to increase of } \\
>1.5 \times \text { ULN }\end{array}$ & $\begin{array}{l}\text { Increase of } \\
1.5-2.5 \times \text { ULN }\end{array}$ & Increase of $>2.5 \times$ ULN & - & - \\
\hline INR & $\begin{array}{l}\text { ULN to increase of } \\
>1.5 \times \text { ULN; increase of } \\
>1-1.5 \times \text { baseline if on } \\
\text { anticoagulation }\end{array}$ & $\begin{array}{l}\text { Increase of } \\
1.5-2.5 \times \text { ULN; increase } \\
\text { of }>1.5-2.5 \times \text { baseline if } \\
\text { on anticoagulation }\end{array}$ & $\begin{array}{l}\text { Increase of }>2.5 \times \text { ULN; } \\
\text { increase of } \\
>2.5 \times \text { baseline if on } \\
\text { anticoagulation }\end{array}$ & - & - \\
\hline Alanine aminotransferase & $\begin{array}{l}\text { ULN to increase of } \\
>3 \times \text { ULN }\end{array}$ & Increase of $3-5 \times$ ULN & Increase of 5-20 × ULN & Increase of $>20 \times$ ULN & - \\
\hline Aspartate aminotransferase & $\begin{array}{l}\text { ULN to increase of } \\
>3 \times \text { ULN }\end{array}$ & Increase of $3-5 \times$ ULN & Increase of $5-20 \times$ ULN & Increase of $>20 \times$ ULN & - \\
\hline Alkaline phosphatase & $\begin{array}{l}\text { ULN to increase of } \\
>2.5 \times \text { ULN }\end{array}$ & Increase of $2.5-5 \times$ ULN & Increase of 5-20 × ULN & Increase of $>20 \times$ ULN & - \\
\hline Lymphocyte count decrease & LLN to $800 / \mathrm{mm}^{3}$ & $500-800 / \mathrm{mm}^{3}$ & $200-500 / \mathrm{mm}^{3}$ & $<200 / \mathrm{mm}^{3}$ & - \\
\hline Platelet count decrease & LLN to $75,000 / \mathrm{mm}^{3}$ & $50,000-75,000 / \mathrm{mm}^{3}$ & $25,000-50,000 / \mathrm{mm}^{3}$ & $<25,000 / \mathrm{mm}^{3}$ & - \\
\hline
\end{tabular}

ULN, upper limit normal; LLN, lower limit normal.

ondansetron are routinely administered prior to treatment. Antinauseants/antiemetics pro re nata (PRN) are usually sufficient to treat nausea/vomiting following treatment.
PAIN

Patients may experience right upper quadrant pain and/or generalized abdominal discomfort. Over the counter analgesics, PRN 
usually treat the discomfort/pain following radioembolization. Stronger analgesics such as opiates are rarely necessary.

\section{COMPLICATIONS DUE TO ABERRANT MICROSPHERE DEPOSITION OR RADIOACTIVITY TO SURROUNDING STRUCTURES HEPATIC DYSFUNCTION}

Pre-existing liver dysfunction is a significant confounding variable when assessing post-radioembolization liver toxicities in HCC patients (30). It is important to classify these cirrhotic patients according to their liver function prior to treatment as previously discussed. A Child-Pugh class C (score of greater or equal to 10) is usually considered a contraindication to locoregional therapies. Patients with elevated baseline bilirubin $(>2 \mathrm{mg} / \mathrm{dL})$ are generally not considered ideal candidates. As the background liver parenchyma is usually normal in patients with hepatic metastases, liver function tests are usually within normal limits. This may not be the case where a majority of the liver is replaced by tumor.

Radiation-induced liver disease (RILD) is a potentially serious post-radioembolization complication (31). Given complexity of radioembolization dosimetry, using the empirical method for dose calculation is not recommended when using SIR-Spheres ${ }^{\circledR}$. The incidence of RILD after ${ }^{90} \mathrm{Y}$ radioembolization ranges from 0 to $4 \%$ (30-32). RILD occurs due to the exposure of normal hepatic parenchyma to radiation. The embolic (ischemic) effect of these microscopic particles is minimal and is not thought to contribute to the hepatotoxicity from radioembolization.

\section{Available data}

A recent article demonstrated repeated radioembolization to be a significant risk factor in development of radioembolization induced liver disease (49). Two of the patients in their eight-patient analysis who had received multiple radioembolization treatments died with clinical features of RILD.

Prior exposure of the liver to external beam radiation therapy (EBRT) may lead to increased liver toxicity after radioembolization. This depends on fractional liver exposure and dose level. The authors concluded that radioembolization appears to be safe for the treatment of hepatic malignancies only in patients who have had limited hepatic exposure to prior EBRT (50).

As biochemical aberrations may occur without clinical manifestations, follow-up liver function tests are routinely recommended 1 month after treatment. In rare cases of clinically manifest RILD, a biopsy of the normal parenchyma may help confirm the diagnosis. A case of post-radioembolization fulminant hepatic failure has been reported (51).

In a single center article analyzing hepatic dysfunction following radioembolization with SIR-Spheres ${ }^{\circledR}$, liver function toxicity (grades 1 through 4 ) was seen in $58 \%$ of infusions. The median duration of LFT toxicities was 20-29 days. Grade 3 or greater toxicities occurred after $9 \%$ of infusions in their analysis. One patient died in 32 days of treatment with signs and symptoms compatible with radiation-induced liver disease (52).

\section{Dose to functional liver}

${ }^{99 \mathrm{~m}}$ Tc-SC SPECT has been used to calculate DFL. ${ }^{99 \mathrm{~m}} \mathrm{Tc}-\mathrm{SC}$ accumulates in normal liver parenchyma due to presence of reticuloendothelial tissue. Increased post-radioembolization liver enzyme elevation was seen with increased DFL (25).

\section{Hepatic fibrosis/portal hypertension}

Pre-existing findings consistent with portal hypertension are not a contraindication to radioembolization. Post-radioembolizaiton hepatic fibrosis and/or portal hypertension are potential posttreatment complications (53). In an analysis by Jakobs et al. (54), 32 patients with secondary hepatic malignancies were selected to exclude the confounding variable of cirrhosis. Mean decrease in hepatic volume was $11.8 \%$ and mean increase in splenic volume was $27.9 \%$ in patients who had undergone bilobar radioembolization. The authors concluded that radioembolization may cause portal hypertension by imaging criteria. However, no patients exhibited any clinical sequelae of portal hypertension. Clinically significant manifestations such as reduced platelet counts $(<100,000 / \mathrm{dL})$ or variceal bleeding are rarely seen following radioembolization.

\section{Radioembolization in patients with transjugular intra-hepatic portosystemic shunts}

Radioembolization can be performed in patients with transjugular intra-hepatic portosystemic shunts (TIPS). An analysis by Memon et al. (55) in patients with TIPS who underwent radioembolization demonstrated new grade $3 / 4$ bilirubin toxicity in $25 \%$ of their patients.

\section{BILIARY SEQUELAE}

Post-radioembolization biliary complications are potential side effects of radioembolization. The incidence of these complications is less than $10 \%$ (33). These may be due to the microembolic effect or radiation-induced injury to the biliary system.

Post-radioembolization biliary complication rates are significantly higher in patients with surgeries/procedures violating the integrity of the ampulla of Vater. ${ }^{90} \mathrm{Y}$ radioembolization in the setting of tumor-related biliary obstruction has an acceptable safety profile (36). Biliary complication incidence is also higher in patients who have had polychyemotherapy. Cirrhosis is found to be protective against biliary complications (35).

These patients usually present with pain and can be evaluated with conventional anatomic imaging techniques (33). Incidentally found biliary sequelae on imaging may be seen. Hence, clinical correlation with the imaging findings is necessary $(56,57)$. Biopsy may be needed in rare cases (34). Following are some biliary complications that have been observed after radioembolization:

\section{Radiation cholecystitis}

Radiation cholecystitis may be prevented by identifying the cystic artery. Microsphere injection distal to its origin and coiling can decrease its incidence. (58). This is schematically seen in Figure 4. Cholecystectomy is the treatment of choice.

\section{Radiation-induced cholangitis}

Fever, jaundice, and right upper quadrant pain may represent radiation-induced cholangitis following radioembolization. Antibiotics may be required. 


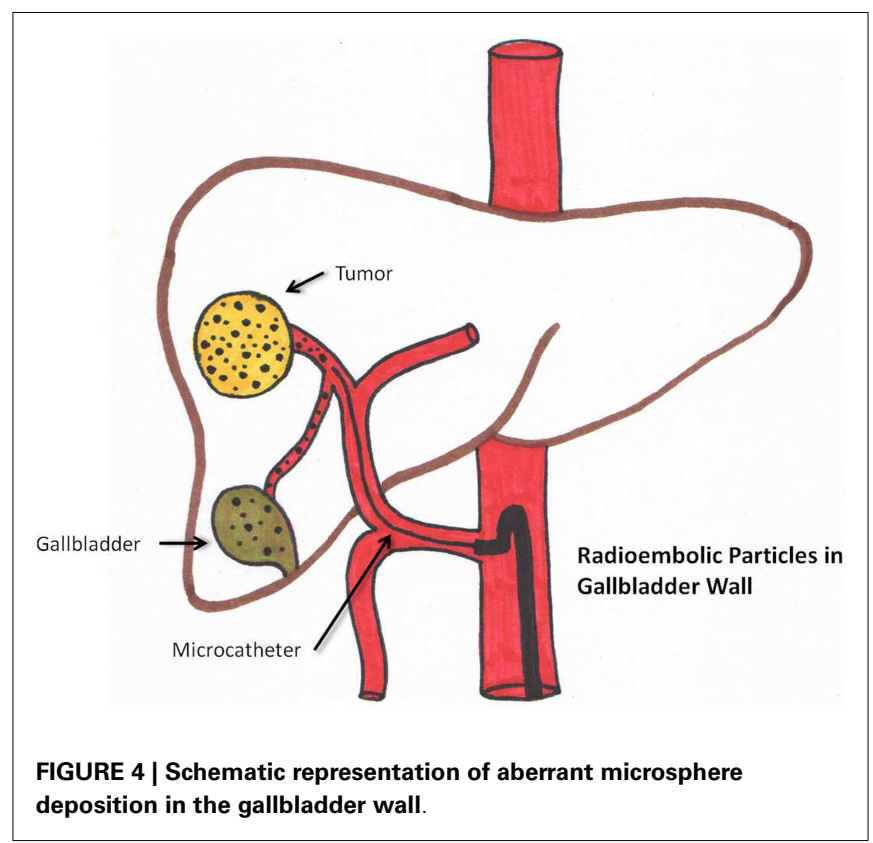

\section{Abscess/bilomas}

Abscesses and bilomas are intra-hepatic fluid collections that may form following radioembolization. Bilomas are usually clinically occult and require conservative management. Abscesses may require percutaneous drainage.

\section{Other}

a) Obstructive jaundice due to biliary strictures

b) Biliary necrosis

\section{RADIATION PNEUMONITIS}

Radiation pneumonitis is very rare (less than $1 \%$ if standard dosimetry models are used) $(35,36)$. This is schematically represented in Figure 5. Please note that if LSF is high, the chance of delivering a high pulmonary dose increases.

Delivery to the lungs of greater than 30 Gray (Gy) in one treatment or a cumulative dose of greater than $50 \mathrm{~Gy}$ in multiple treatments is considered a relative contraindication. Planar scintigraphy is usually employed to calculate LSF. Yu et al. described a new method of calculating the mean lung dose for TheraSphere $^{\circledR}$ and SIR-Sphere ${ }^{\circledR}$ radioembolization of liver cancer based on ${ }^{99 \mathrm{~m}} \mathrm{Tc}$-MAA SPECT/CT. According to Yu et al., this method provides a more accurate estimate of radiation risk to the lungs (59). However, this is not routinely performed currently.

A restrictive ventilatory dysfunction following radioembolization has been reported (60). Radiation pneumonitis can be seen as a typical bat-wing appearance on chest CT (35). Data presented by Salem et al. demonstrated a very low incidence of post-radioembolization pulmonary complication (36).

Steroids may play a role in management. Other thoracic complications include atelectasis and/or pleural effusion.

\section{GASTROINTESTINAL (GI) COMPLICATIONS Diarrhea}

Diarrhea has been described following radioembolization. This is rarely significant enough to require hospitalization.

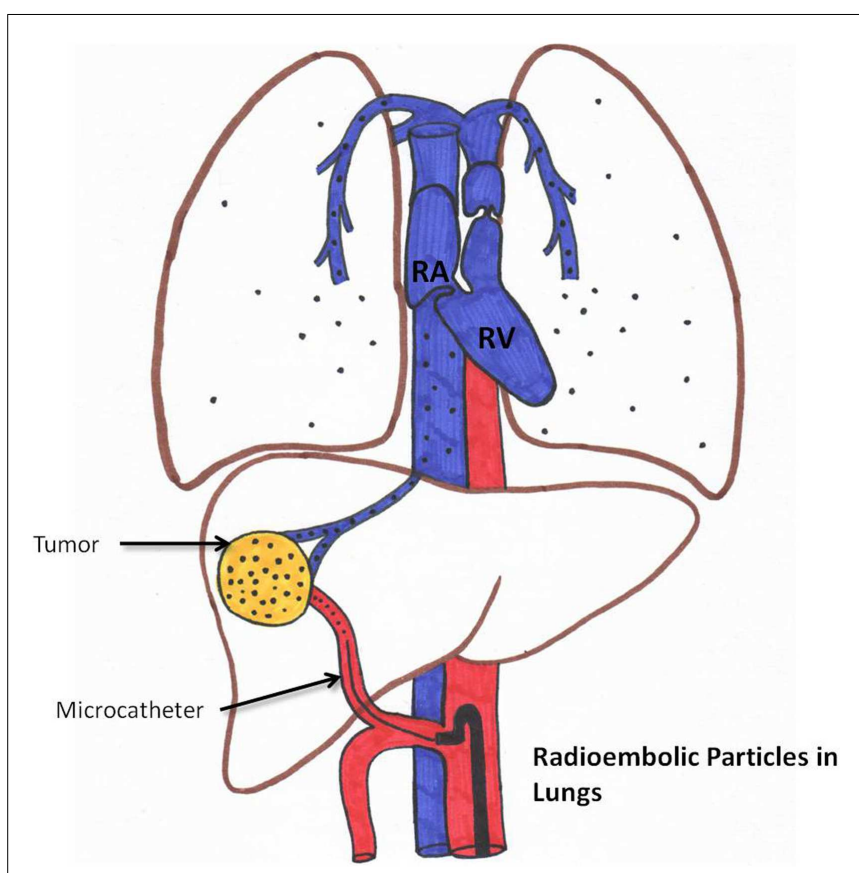

FIGURE 5 | Schematic representation of aberrant microsphere deposition in the lungs.

\section{Gastroenteritis/gastrointestinal ulcera}

Post-radioembolization GI complications occur secondary to hepaticoenteric arterial communications resulting in aberrant microsphere deposition (37). Recognition of these hepaticoenteric arterial communications is essential (38). This is schematically represented in Figure 6. Incidence of GI complications is less than 5\% (37-40).

Prophylactic coil embolization of the gastroduodenal and RGA may be considered. The left hepatic angiogram is performed to identify left gastric and inferior esophageal arteries. Delayed angiography of the left hepatic artery with opacification of the coronary vein confirms hepaticoenteric flow. The right hepatic angiogram is required to identify the supraduodenal and retroportal arteries (23).

Prophylactic use of gastric acid suppressive agents (such as proton pump inhibitors) is recommended. If GI ulceration is clinically suspected, endoscopy is recommended to confirm the diagnosis $(39,61)$.

A recent root cause analysis showed stasis during injection to be the strongest independent risk factor for development of gastroduodenal complications (42). Distal origin of the GDA, young age $(p=0.04)$, and proximal injection of the microspheres were also significant risk factors.

A potential complication of coil embolization of vessels, such as the GDA and RGA, is formation of collateral hepaticoenteric flow. This can result in increased enteric complications on repeat treatments.

\section{ACUTE PANCREATITIS}

Acute pancreatitis is a potential but very rare complication of radioembolization (62). Patients present with severe epigastric or 


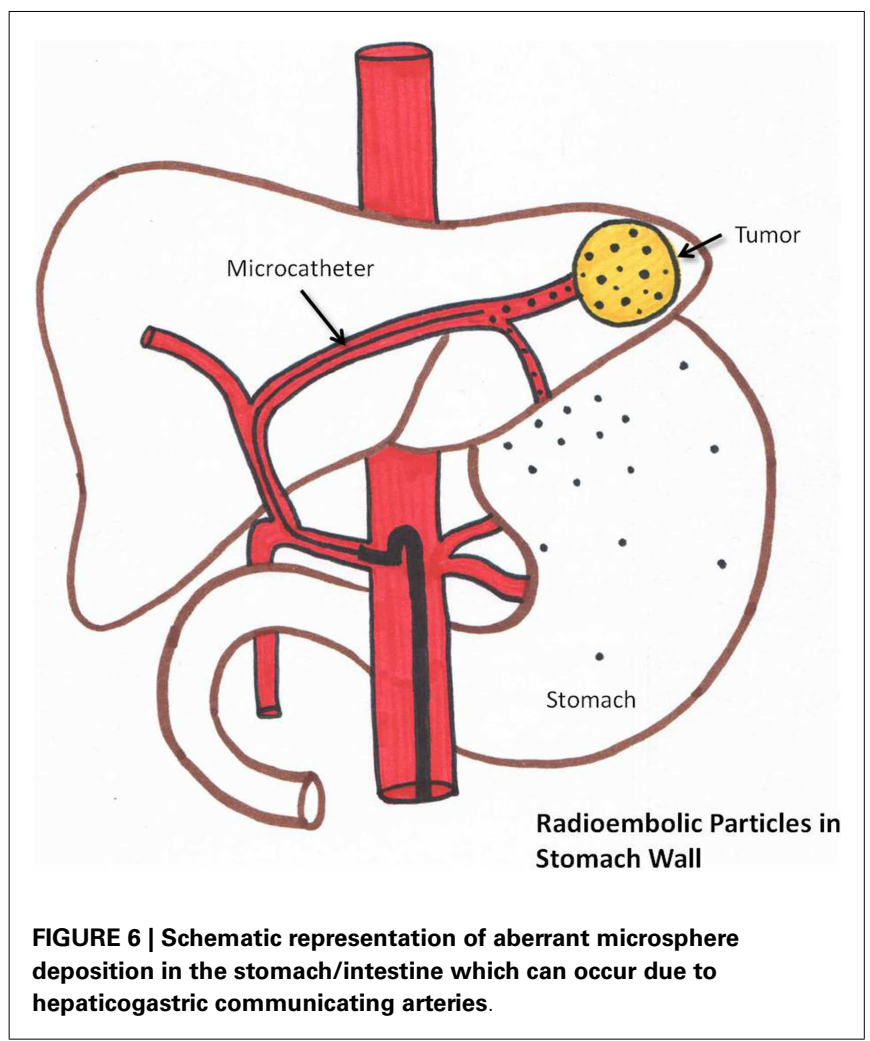

periumbilical pain. Serum lipase and amylase levels are usually elevated. Imaging may be helpful to determine other causes of acute pancreatitis. SPECT/CT to detect ${ }^{90} \mathrm{Y}$ Bremsstrahlung in the pancreas may be performed. Treatment is conservative.

\section{RADIATION DERMATITIS}

Periumbilical pain may occur due to aberrant microsphere deposition in the anterior abdominal wall via the falciform artery (16, 19, 20). Radiation dermatitis is rare.

Recognition of the falciform artery is essential. Prophylactic embolization of this vessel can be performed if needed to decrease the incidence of radiation dermatitis. Prophylactic topically applied ice prevents complications as it causes vasoconstriction which decreases cutaneous flow (63).

\section{LYMPHOPENIA}

Lymphopenia may be seen after glass microsphere radioembolization. Greater than 25\% decrease in lymphocyte count after treatment is seen in the majority of patients $(45,64)$. However, no opportunistic infections due to the lymphopenia after radioembolization have been reported $(45,64)$.

\section{OTHER COMPLICATIONS THROMBOCYTOPENIA}

A retrospective analysis demonstrated thrombocytopenia as a complication following radioembolization. Splenomegaly can be seen following radioembolization which was shown to be an independent risk factor for development of a low platelet count (65). No significant bleeding diathesis has been reported due to thrombocytopenia following radioembolization.

\section{VASCULAR INJURY}

The incidence of vascular injury may be prevented by the following:

a) Knowledge of prior anti-cancer therapy

b) Stopping and resuming "blood thinners" appropriately

c) Reviewing cross-sectional anatomy to determine vascular anatomy such as the furcation of the common femoral artery.

\section{Dissection}

Newer anti-cancer drugs such as bevacizumab (Avastin) have been shown to make vasculature more friable and prone to injury, increasing the chances of dissection and vascular rupture. Abnormalities in vasculature and hepatic arterial flow in 12/16 (75\%) patients who were on anti-cancer therapy has been reported. During angiography, a search for stenoses and abnormal flow should be undertaken (66). Murthy et al. (67) demonstrated a reasonable safety profile of radioembolization with resin microspheres in 10 patients who had been on cetuximab or bevacizumab. Usage of microcatheters and careful wire/catheter manipulation is recommended in patients on or previously exposed to systemic anti-cancer therapy.

Dissection at the site of arteriotomy is rare but possible. A pre-closure common femoral angiogram assists in its diagnosis. However, this may not be routinely performed. The patient may present with a "cold" extremity and stenting/anti-platelet therapy may be required.

\section{Bleeding}

Hematoma formation at the arteriotomy may be seen in radioembolization (68). Standard protocols mitigating bleeding such as stopping "blood thinners" and making sure the patient's coagulation profile is within normal limits should be meticulously employed (69). Manual compression may be necessary. Surgical intervention is very rarely required.

If there is suspicion of pseudoaneurysm formation, ultrasound with Doppler may be needed. This is usually treated with ultrasound guided manual compression. Thrombin injection may be performed if necessary. Surgery is rarely necessary.

\section{CONTRAST INDUCED NEPHROTOXICITY}

It is important to know the patient's baseline renal function prior to performing transarterial therapies such as radioembolization. Adequate hydration pre- and post-radioembolization and stringent use of iodinated contrast limit contrast induced nephrotoxicity.

\section{ALLERGIC REACTION TO IODINATED CONTRAST MEDIA}

Anticipation of possible allergic reactions is essential. Most patients being considered for radioembolization have received prior iodinated contrast media for CT scans. An allergic reaction can range from a minor reaction such as a pruritic rash to an anaphylactoid reaction. If there is a history of prior minor allergic reactions (such as hives) to iodinated contrast, the patient may still received iodinated contrast after receiving an allergy preparation prior to planned transarterial procedure (usually a combination of steroids and anti-histamines). 


\section{ACUTE CHILLS}

Acute chills may occur during treatment, which usually respond to anti-histamines (70).

\section{CONCLUSION}

Radioembolization is being employed for treatment of various hepatic malignancies. As with any other common therapy, knowledge of potential complications of this therapy is essential. Selecting appropriate patients using a multidisciplinary approach can improve outcomes and decrease complications. Meticulous pretreatment planning (angiography and ${ }^{99 \mathrm{~m}}$ Tc-MAA scintigraphic imaging) is necessary to minimize side effects of radioembolization. The incidence of complications that may require intervention is low. Grade 3 or higher complications following radioembolization occur in less than $9 \%$ of patients. Aberrant microsphere deposition may lead to various complications such as radiation cholecystitis. Surgical therapy may be required in severe cases. As radioembolization is a transarterial procedure, knowledge of general complications associated with transarterial therapies is also important.

\section{REFERENCES}

1. Parkin DM, Bray F, Ferlay J, Pisani P. Global cancer statistics, 2002. CA Cancer J Clin (2005) 55(2):74-108. doi:10.3322/canjclin.55.2.74

2. Bosch FX, Ribes J, Diaz M, Cleries R. Primary liver cancer: worldwide incidence and trends. Gastroenterology (2004) 127(5 Suppl 1):S5-16. doi:10.1053/j.gastro. 2004.09.011

3. Michel J, Suc B, Montpeyroux F, Hachemanne S, Blanc P, Domergue J, et al. Liver resection or transplantation for hepatocellular carcinoma? Retrospective analysis of 215 patients with cirrhosis. J Hepatol (1997) 26(6):1274-80. doi:10.1016/S0168-8278(97)80462-X

4. Mazzaferro V, Regalia E, Doci R, Andreola S, Pulvirenti A, Bozzetti F, et al. Liver transplantation for the treatment of small hepatocellular carcinomas in patients with cirrhosis. N Engl J Med (1996) 334(11):693-9. doi:10.1056/ NEJM199603143341104

5. Lencioni R, Crocetti L. Radiofrequency ablation of liver cancer. Tech Vasc Interv Radiol (2007) 10(1):38-46. doi:10.1053/j.tvir.2007.08.006

6. Takayasu K, Arii S, Ikai I, Omata M, Okita K, Ichida T, et al. Prospective cohort study of transarterial chemoembolization for unresectable hepatocellular carcinoma in 8510 patients. Gastroenterology (2006) 131(2):461-9. doi:10.1053/j.gastro.2006.05.021

7. Lewandowski RJ, Thurston KG, Goin JE, Wong CY, Gates VL, Van Buskirk M, et al. 90Y microsphere (TheraSphere) treatment for unresectable colorectal cancer metastases of the liver: response to treatment at targeted doses of 135-150 Gy as measured by [18F]fluorodeoxyglucose positron emission tomography and computed tomographic imaging. J Vasc Interv Radiol (2005) 16(12):1641-51. doi:10.1097/01.RVI.0000179815.44868.66

8. Gray B, Van Hazel G, Hope M, Burton M, Moroz P, Anderson J, et al. Randomised trial of SIR-Spheres plus chemotherapy vs. chemotherapy alone for treating patients with liver metastases from primary large bowel cancer. Ann Oncol (2001) 12(12):1711-20. doi:10.1023/A:1013569329846

9. Rhee TK, Lewandowski RJ, Liu DM, Mulcahy MF, Takahashi G, Hansen PD, et al. 90Y Radioembolization for metastatic neuroendocrine liver tumors: preliminary results from a multi-institutional experience. Ann Surg (2008) 247(6):1029-35. doi:10.1097/SLA.0b013e3181728a45

10. Kennedy AS, Dezarn WA, McNeillie P, Coldwell D, Nutting C, Carter D, et al. Radioembolization for unresectable neuroendocrine hepatic metastases using resin 90Y-microspheres: early results in 148 patients. Am J Clin Oncol (2008) 31(3):271-9. doi:10.1097/COC.0b013e31815e4557

11. SIR-Spheres Yttrium-90 Microspheres Package Insert, SIRTeX Medical. Lane Cove (2004).

12. TheraSphere Yttrium-90 Microspheres Package Insert, MDS Nordion. Kanata (2004).

13. Bester L, Feitelson S, Milner B, Chua TC, Morris DL. Impact of prior hepatectomy on the safety and efficacy of radioembolization with yttrium-90 microspheres for patients with unresectable liver tumors. Am J Clin Oncol (2013). doi:10.1097/COC.0b013e31827deeal

14. van den Hoven AF, Smits ML, de Keizer B, van Leeuwen MS, van den Bosch MA, Lam MG. Identifying aberrant hepatic arteries prior to intra-arterial radioembolization. Cardiovasc Intervent Radiol (2014). doi:10.1007/s00270-014-0845-x

15. Yoon CJ, Chung JW, Cho BH, Jae HJ, Kang SG, Kim HC, et al. Hepatocellular carcinoma in the caudate lobe of the liver: angiographic analysis of tumorfeeding arteries according to subsegmental location. J Vasc Interv Radiol (2008) 19(11):1543-50;quiz50. doi:10.1016/j.jvir.2008.07.008

16. Liu DM, Salem R, Bui JT, Courtney A, Barakat O, Sergie Z, et al. Angiographic considerations in patients undergoing liver-directed therapy. J Vasc Interv Radiol (2005) 16(7):911-35. doi:10.1097/01.RVI.0000164324.79242.B2

17. Murthy R, Nunez R, Szklaruk J, Erwin W, Madoff DC, Gupta S, et al. Yttrium90 microsphere therapy for hepatic malignancy: devices, indications, technical considerations, and potential complications. Radiographics (2005) 25(Suppl 1):S41-55. doi:10.1148/rg.25si055515

18. Cosin O, Bilbao JI, Alvarez S, de Luis E, Alonso A, Martinez-Cuesta A. Right gastric artery embolization prior to treatment with yttrium-90 microspheres. Cardiovasc Intervent Radiol (2007) 30(1):98-103. doi:10.1007/s00270-006-0028-5

19. Salem R, Lewandowski RJ, Sato KT, Atassi B, Ryu RK, Ibrahim S, et al. Technical aspects of radioembolization with $90 \mathrm{Y}$ microspheres. Tech Vasc Interv Radiol (2007) 10(1):12-29. doi:10.1053/j.tvir.2007.08.001

20. Lewandowski RJ, Sato KT, Atassi B, Ryu RK, Nemcek AA Jr., Kulik L, et al. Radioembolization with 90Y microspheres: angiographic and technical considerations. Cardiovasc Intervent Radiol (2007) 30(4):571-92. doi:10.1007/s00270007-9064-Z

21. van den Hoven AF, Smits ML, Rosenbaum CE, Verkooijen HM, van den Bosch MA, Lam MG. The effect of intra-arterial angiotensin II on the hepatic tumor to non-tumor blood flow ratio for radioembolization: a systematic review. PLoS One (2014) 9(1):e86394. doi:10.1371/journal.pone.0086394

22. Meyer C, Pieper CC, Ezziddin S, Wilhelm KE, Schild HH, Ahmadzadehfar H. Feasibility of temporary protective embolization of normal liver tissue using degradable starch microspheres during radioembolization of liver tumours. Eur J Nucl Med Mol Imaging (2014) 41(2):231-7. doi:10.1007/s00259-013-2550-4

23. Hamami ME, Poeppel TD, Muller S, Heusner T, Bockisch A, Hilgard P, et al. SPECT/CT with 99mTc-MAA in radioembolization with $90 \mathrm{Y}$ microspheres in patients with hepatocellular cancer. J Nucl Med (2009) 50(5):688-92. doi:10.2967/jnumed.108.058347

24. Sabet A, Ahmadzadehfar H, Muckle M, Haslerud T, Wilhelm K, Biersack HJ, et al. Significance of oral administration of sodium perchlorate in planning liver-directed radioembolization. J Nucl Med (2011) 52(7):1063-7. doi:10.2967/ jnumed.110.083626

25. Lam MG, Goris ML, Iagaru AH, Mittra ES, Louie JD, Sze DY. Prognostic utility of $90 \mathrm{Y}$ radioembolization dosimetry based on fusion $99 \mathrm{mTc}$-macroaggregated albumin-99mTc-sulfur colloid SPECT. J Nucl Med (2013) 54(12):2055-61. doi:10.2967/jnumed.113.123257

26. Pasciak AS, Bourgeois AC, McKinney JM, Chang TT, Osborne DR, Acuff SN, et al. Radioembolization and the dynamic role of (90)Y PET/CT. Front Oncol (2014) 4:38. doi:10.3389/fonc.2014.00038

27. Gates VL, Marshall KG, Salzig K, Williams M, Lewandowski RJ, Salem R. Outpatient single-session yttrium-90 glass microsphere radioembolization. J Vasc Interv Radiol (2014) 25(2):266-70. doi:10.1016/j.jvir.2013.11.005

28. Gupta A, Gill A, Shrikanthan S, Srinivas S. Nontargeted Y-90 microsphere radioembolization to duodenum visualized on Y-90 PET/CT and Bremsstrahlung SPECT/CT. Clin Nucl Med (2012) 37(1):98-9. doi:10.1097/ RLU.0b013e318233650b

29. Riaz A, Lewandowski RJ, Kulik LM, Mulcahy MF, Sato KT, Ryu RK, et al. Complications following radioembolization with yttrium-90 microspheres: a comprehensive literature review. J Vasc Interv Radiol (2009) 20(9):1121-30;quiz31. doi:10.1016/j.jvir.2009.05.030

30. Young JY, Rhee TK, Atassi B, Gates VL, Kulik L, Mulcahy MF, et al. Radiation dose limits and liver toxicities resulting from multiple yttrium-90 radioembolization treatments for hepatocellular carcinoma. J Vasc Interv Radiol (2007) 18(11):1375-82. doi:10.1016/j.jvir.2007.07.016

31. Sangro B, Gil-Alzugaray B, Rodriguez J, Sola I, Martinez-Cuesta A, Viudez A, et al. Liver disease induced by radioembolization of liver tumors: description and possible risk factors. Cancer (2008) 112(7):1538-46. doi:10.1002/cncr.23339

32. Kennedy AS, McNeillie P, Dezarn WA, Nutting C, Sangro B, Wertman D, et al. Treatment parameters and outcome in 680 treatments of internal radiation with 
resin yttrium-90 microspheres for unresectable hepatic tumors. Int J Radiat Oncol Biol Phys (2009) 74(5):1494-500. doi:10.1016/j.ijrobp.2008.10.005

33. Atassi B, Bangash AK, Lewandowski RJ, Ibrahim S, Kulik L, Mulcahy MF, et al. Biliary sequelae following radioembolization with yttrium-90 microspheres. J Vasc Interv Radiol (2008) 19(5):691-7. doi:10.1016/j.jvir.2008.01.003

34. Ng SS, Yu SC, Lai PB, Lau WY. Biliary complications associated with selective internal radiation (SIR) therapy for unresectable liver malignancies. Dig Dis Sci (2008) 53(10):2813-7. doi:10.1007/s10620-008-0222-1

35. Leung TW, Lau WY, Ho SK, Ward SC, Chow JH, Chan MS, et al. Radiation pneumonitis after selective internal radiation treatment with intraarterial 90yttriummicrospheres for inoperable hepatic tumors. Int J Radiat Oncol Biol Phys (1995) 33(4):919-24. doi:10.1016/0360-3016(95)00039-3

36. Salem R, Parikh P, Atassi B, Lewandowski RJ, Ryu RK, Sato KT, et al. Incidence of radiation pneumonitis after hepatic intra-arterial radiotherapy with yttrium90 microspheres assuming uniform lung distribution. Am J Clin Oncol (2008) 31(5):431-8. doi:10.1097/COC.0b013e318168ef65

37. Carretero C, Munoz-Navas M, Betes M, Angos R, Subtil JC, Fernandez-Urien $\mathrm{I}$, et al. Gastroduodenal injury after radioembolization of hepatic tumors. Am J Gastroenterol (2007) 102(6):1216-20. doi:10.1111/j.1572-0241.2007. 01172.x

38. Murthy R, Brown DB, Salem R, Meranze SG, Coldwell DM, Krishnan S, et al. Gastrointestinal complications associated with hepatic arterial Yttrium90 microsphere therapy. J Vasc Interv Radiol (2007) 18(4):553-61;quiz62. doi:10.1016/j.jvir.2007.02.002

39. Mallach S, Ramp U, Erhardt A, Schmitt M, Haussinger D. An uncommon cause of gastro-duodenal ulceration. World J Gastroenterol (2008) 14(16):2593-5. doi:10.3748/wjg.14.2593

40. Szyszko T, Al-Nahhas A, Tait P, Rubello D, Canelo R, Habib N, et al. Management and prevention of adverse effects related to treatment of liver tumours with 90Y microspheres. Nucl Med Commun (2007) 28(1):21-4. doi:10.1097/MNM. 0b013e3280121a8f

41. South CD, Meyer MM, Meis G, Kim EY, Thomas FB, Rikabi AA, et al. Yttrium-90 microsphere induced gastrointestinal tract ulceration. World J Surg Oncol (2008) 6:93. doi:10.1186/1477-7819-6-93

42. Lam MG, Banerjee S, Louie JD, Abdelmaksoud MH, Iagaru AH, Ennen RE, et al. Root cause analysis of gastroduodenal ulceration after yttrium-90 radioembolization. Cardiovasc Intervent Radiol (2013) 36(6):1536-47. doi:10.1007/ s00270-013-0579-1

43. NCI. Common Terminology Criteria for Adverse Events (CTCAE) Version 4.0. (2009). Available from: http://evs.nci.nih.gov/ftp1/CTCAE/CTCAE_4.03 2010-06-14_QuickReference_5x7.pdf

44. Kennedy AS, Coldwell D, Nutting C, Murthy R, Wertman DE Jr., Loehr SP, et al. Resin 90Y-microsphere brachytherapy for unresectable colorectal liver metastases: modern USA experience. Int J Radiat Oncol Biol Phys (2006) 65(2):412-25. doi:10.1016/j.ijrobp.2005.12.051

45. Salem R, Lewandowski RJ, Atassi B, Gordon SC, Gates VL, Barakat O, et al. Treatment of unresectable hepatocellular carcinoma with use of $90 \mathrm{Y}$ microspheres (TheraSphere): safety, tumor response, and survival. J Vasc Interv Radiol (2005) 16(12):1627-39. doi:10.1097/01.RVI.0000184594.01661.81

46. Murthy R, Xiong H, Nunez R, Cohen AC, Barron B, Szklaruk J, et al. Yttrium 90 resin microspheres for the treatment of unresectable colorectal hepatic metastases after failure of multiple chemotherapy regimens: preliminary results. J Vasc Interv Radiol (2005) 16(7):937-45. doi:10.1097/01.RVI.0000161142. 12822.66

47. Sato K, Lewandowski RJ, Bui JT, Omary R, Hunter RD, Kulik L, et al. Treatment of unresectable primary and metastatic liver cancer with yttrium-90 microspheres (TheraSphere): assessment of hepatic arterial embolization. Cardiovasc Intervent Radiol (2006) 29(4):522-9. doi:10.1007/s00270-005-0171-4

48. Peterson JL, Vallow LA, Johnson DW, Heckman MG, Diehl NN, Smith AA, et al. Complications after 90Y microsphere radioembolization for unresectable hepatic tumors: an evaluation of 112 patients. Brachytherapy (2013) 12(6):573-9. doi:10.1016/j.brachy.2013.05.008

49. Lam MG, Louie JD, Iagaru AH, Goris ML, Sze DY. Safety of repeated yttrium90 radioembolization. Cardiovasc Intervent Radiol (2013) 36(5):1320-8. doi:10. 1007/s00270-013-0547-9

50. Lam MG, Abdelmaksoud MH, Chang DT, Eclov NC, Chung MP, Koong AC, et al. Safety of $90 \mathrm{Y}$ radioembolization in patients who have undergone previous external beam radiation therapy. Int J Radiat Oncol Biol Phys (2013) 87(2):323-9. doi:10.1016/j.ijrobp.2013.05.041
51. Hamoui N, Ryu RK. Hepatic radioembolization complicated by fulminan hepatic failure. Semin Intervent Radiol (2011) 28(2):246-51. doi:10.1055/s0031-1280674

52. Piana PM, Gonsalves CF, Sato T, Anne PR, McCann JW, Bar Ad V, et al. Toxicities after radioembolization with yttrium-90 SIR-spheres: incidence and contributing risk factors at a single center. J Vasc Interv Radiol (2011) 22(10):1373-9. doi:10.1016/j.jvir.2011.06.006

53. Ayav A, Habib N, Jiao LR. Portal hypertension secondary to 90Yttrium microspheres: an unknown complication. J Clin Oncol (2005) 23(32):8275-6. doi:10.1200/JCO.2005.03.7820

54. Jakobs TF, Saleem S, Atassi B, Reda E, Lewandowski RJ, Yaghmai V, et al. Fibrosis, portal hypertension, and hepatic volume changes induced by intra-arterial radiotherapy with (90)yttrium microspheres. Dig Dis Sci (2008) 53(9):2556-63. doi:10.1007/s10620-007-0148-z

55. Memon K, Kulik L, Lewandowski RJ, Mulcahy MF, Benson AB, Ganger D, et al. Radioembolization for hepatocellular carcinoma with portal vein thrombosis: impact of liver function on systemic treatment options at disease progression. $J$ Hepatol (2013) 58(1):73-80. doi:10.1016/j.jhep.2012.09.003

56. Rhee TK, Naik NK, Deng J, Atassi B, Mulcahy MF, Kulik LM, et al. Tumor response after yttrium-90 radioembolization for hepatocellular carcinoma: comparison of diffusion-weighted functional MR imaging with anatomic MR imaging. J Vasc Interv Radiol (2008) 19(8):1180-6. doi:10.1016/j.jvir.2008. 05.002

57. Ibrahim SM, Nikolaidis P, Miller FH, Lewandowski RJ, Ryu RK, Sato KT, et al. Radiologic findings following Y90 radioembolization for primary liver malig nancies. Abdom Imaging (2009) 34(5):566-81. doi:10.1007/s00261-008-9454-y

58. Salem R, Thurston KG. Radioembolization with 90yttrium microspheres: a state-of-the-art brachytherapy treatment for primary and secondary liver malignancies: part 2: special topics. J Vasc Interv Radiol (2006) 17(9):1425-39. doi:10.1097/01.RVI.0000235779.88652.53

59. Yu N, Srinivas SM, Difilippo FP, Shrikanthan S, Levitin A, McLennan G, et al. Lung dose calculation with SPECT/CT for (9)(0)Yittrium radioembolization of liver cancer. Int J Radiat Oncol Biol Phys (2013) 85(3):834-9. doi:10.1016/j.ijrobp.2012.06.051

60. Wright CL, Werner JD, Tran JM, Gates VL, Rikabi AA, Shah MH, et al. Radiation pneumonitis following yttrium-90 radioembolization: case report and literature review. J Vasc Interv Radiol (2012) 23(5):669-74. doi:10.1016/j.jvir. 2012.01.059

61. Veloso N, Brandao C, Goncalves B, Costa L, Coimbra N, Jacome M, et al. Gastroduodenal ulceration following liver radioembolization with yttrium-90. Endoscopy (2013) 45(Suppl 2 UCTN):E108-9. doi:10.1055/s-0032-1326346

62. Hoffmann RT, Jakobs TF, Kubisch CH, Stemmler HJ, Trumm C, Tatsch K, et al. Radiofrequency ablation after selective internal radiation therapy with Yttrium90 microspheres in metastatic liver disease-Is it feasible? Eur J Radiol (2010) 74(1):199-205. doi:10.1016/j.ejrad.2009.02.001

63. Wang DS, Louie JD, Kothary N, Shah RP, Sze DY. Prophylactic topically applied ice to prevent cutaneous complications of nontarget chemoembolization and radioembolization. J Vasc Interv Radiol (2013) 24(4):596-600. doi:10.1016/j. jvir.2012.12.020

64. Carr BI. Hepatic arterial 90Yttrium glass microspheres (Therasphere) for unresectable hepatocellular carcinoma: interim safety and survival data on 65 patients. Liver Transpl (2004) 10(2 Suppl 1):S107-10. doi:10.1002/lt.20036

65. Lam MG, Banerjee A, Louie JD, Sze DY. Splenomegaly-associated thrombocytopenia after hepatic yttrium-90 radioembolization. Cardiovasc Intervent Radiol (2014) 37(4):1009-17. doi:10.1007/s00270-013-0742-8

66. Wiggins E, Ibrahim SM, Lewandowski RJ, Sato KT, Omary RA, Salem R. Abstract No. 124: effect of chemotherapy on hepatic vasculature in patients undergoing y-90 radioembolization for metastatic disease. J Vasc Interv Radiol (2008) 19(2):S48-9. doi:10.1016/j.jvir.2007.12.138

67. Murthy R, Eng C, Krishnan S, Madoff DC, Habbu A, Canet S, et al. Hepatic yttrium-90 radioembolotherapy in metastatic colorectal cancer treated with cetuximab or bevacizumab. J Vasc Interv Radiol (2007) 18(12):1588-91. doi: 10.1016/j.jvir.2007.08.015

68. Lilly MP, Reichman W, Sarazen AA Jr., Carney WI Jr. Anatomic and clinical factors associated with complications of transfemoral arteriography. Ann Vasc Surg (1990) 4(3):264-9. doi:10.1007/BF02009455

69. Douketis JD, Spyropoulos AC, Spencer FA, Mayr M, Jaffer AK, Eckman MH, et al. Perioperative management of antithrombotic therapy: antithrombotic therapy and prevention of thrombosis, 9th ed: American College of Chest 
Physicians Evidence-Based Clinical Practice Guidelines. Chest (2012) 141(2 Suppl):326S-50S. doi:10.1378/chest.11-2298

70. Salem R, Thurston KG. Radioembolization with 90yttrium microspheres: a state-of-the-art brachytherapy treatment for primary and secondary liver malignancies: part 1: technical and methodologic considerations. J Vasc Interv Radiol (2006) 17(8):1251-78. doi:10.1097/01.RVI.0000233785.75257.9A

Conflict of Interest Statement: Riad Salem receives research support from Nordion. The other co-authors declare that the research was conducted in the absence of any commercial or financial relationships that could be construed as a potential conflict of interest.
Received: 30 March 2014; accepted: 15 July 2014; published online: 29 July 2014. Citation: Riaz A, Awais $R$ and Salem $R$ (2014) Side effects of yttrium-90 radioembolization. Front. Oncol. 4:198. doi: 10.3389/fonc.2014.00198

This article was submitted to Cancer Imaging and Diagnosis, a section of the journal Frontiers in Oncology.

Copyright () 2014 Riaz, Awais and Salem. This is an open-access article distributed under the terms of the Creative Commons Attribution License (CC BY). The use, distribution or reproduction in other forums is permitted, provided the original author(s) or licensor are credited and that the original publication in this journal is cited, in accordance with accepted academic practice. No use, distribution or reproduction is permitted which does not comply with these terms. 